\title{
Factors Influencing Classroom Participation of Undergraduate Nursing Students
}

\author{
Doreen Asantewa Abeasi, Paul Adjei Kwakwa \\ Department of Nursing, Presbyterian University College, Ghana
}

reenasantewa@gmail.com

First draft received: 11 Nov 2019 Date Accepted: 17 Feb 2020 Final proof received: 10 May2020

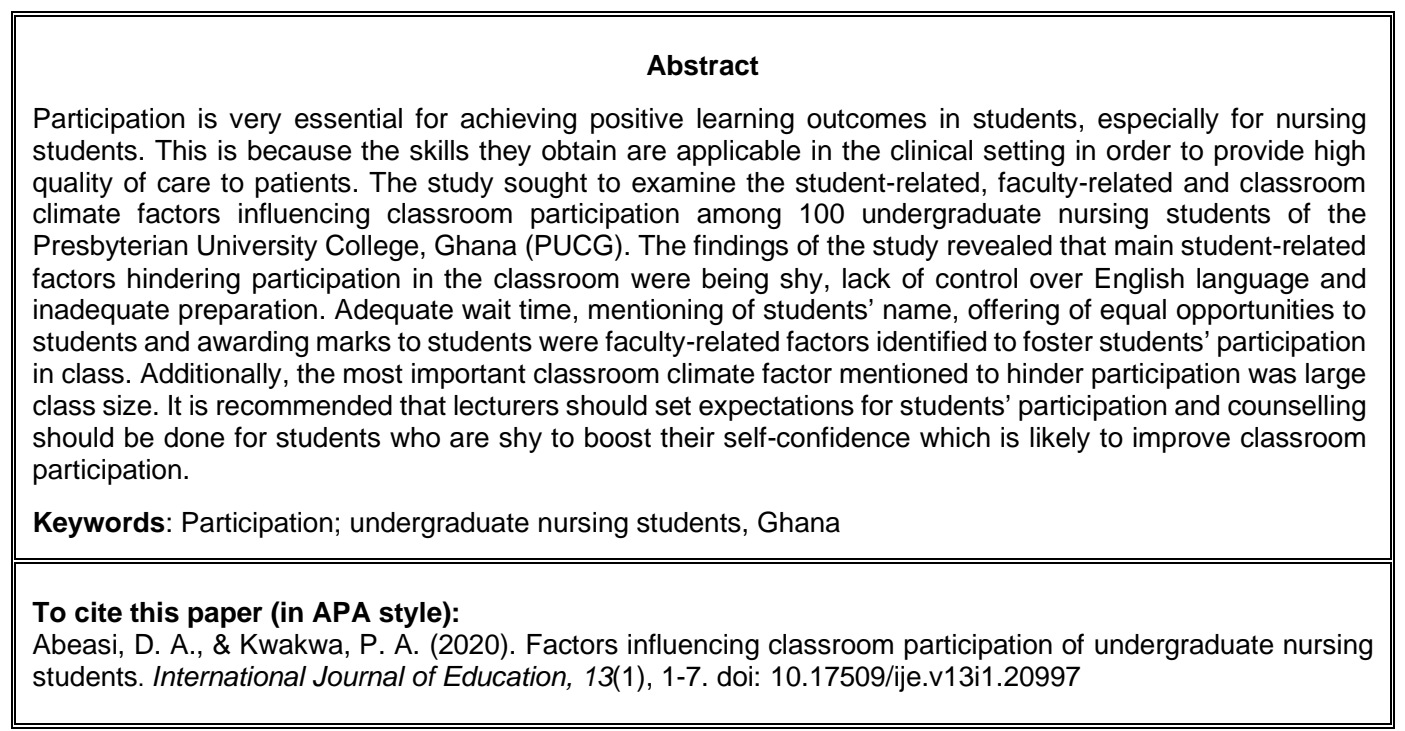

\section{INTRODUCTION}

Nursing, one of the pillars of the health care institution, has been described as very dynamic because it continues to evolve day in and day out. As a result, innovative problem-solving skills are needed to address inherent challenges as well as incorporating new knowledge and technology that may impact care (Benner et al., 2010). The nursing faculty has a key role in providing student nurses with a foundation for problem-solving skills (Tedesco-Schneck, 2016; Lau, 2014) which can be achieved through promoting student-centered teaching methods that foster active learning supported by active classroom participation. The concept of classroom participation means more than just a question and answer section between the lecturer and the student (McCleary et al., 2011; Rocca, 2010). Many types have been described by different researchers. They include; spontaneous or volunteer (Weaver \& Qi, 2005; Fassinger, 1995), required or graded (Daggett, 1997), passive (Weaver \& Qi, 2005), para participation (Billings \& Haltstead, 2009), negative (Howard \& Henney, 1998), compulsory (Dallimore et al., 2004), non-participation (Weaver \& Qi, 2005), active (Mustapha et al., 2010) and passive (Loftin, Davis \& Hartin, 2014).

Classroom participation is an essential ingredient for active learning, yet it has been found that many nursing students do not participate in class (Pokess \& McDaniel, 2011). Positive learning outcomes are closely related to classroom participation such that students who get involved have been reported to demonstrate an improvement in their communication skills (Dancer \& Kamvounias, 2005), group interactions, and functioning in a democratic society (Girgin \& Stevens, 2005). Again, it helps the student to demonstrate understanding of the concepts and ability to think critically (Garside, 1996). Students who are not confident enough through participation begin to improve on their confidence level. Route learning is minimized when classroom participation is high (Rocca, 2010). Communication, critical ability and confidence are very important in preparing student nurses for their careers and life as well.

Some researchers have identified student confidence as a key factor in influencing classroom participation (Susak, 2016; Kheleghi, 2016; Moffet et al., 2014). Others have also found lack of preparation and fear of making mistakes (Abebe \& Deneke, 2015; Mustapha et al., 2010) as inhibiting participation. Classroom participation has been found to be affected by the lecturer's relationship with students (TedescoSchneck, 2016), teaching skills (Abebe \& Deneke, 2015; Nunn, 1996), criticisms of students' responses (Susak, 2016; Abebe \& Deneke, 2015) and course policies by the lecturer. In addition to the above, classroom climate factors which have been reported by studies to affect participation are small class size (Susak, 2016; Moffet et al., 2014) and classroom arrangement (Abebe \& Deneke, 2015; Rocca, 2010).

A significant proportion of the studies on students' classroom participation has been devoted to students in secondary schools (Aziz et al., 2018; Phelps et al., 
2012; Fassinger, 1995), however, classrooms containing adults or young adults especially university students is increasingly becoming popular in recent times. Among those that have examined the case of university students, some have focused on undergraduate students' participation in English classrooms (Abebe \& Deneke 2015); participation in communication subjects (Mustapha, Rahman and Yunus, 2010); graduate students' participation in classrooms (Tatar, 2005) while some have examined a combination of undergraduate and graduate students' participation (Abdullah et al., 2012, Weaver \& Qi, 2005). Those studies done on undergraduate students (Ballen et al., 2017; Abebe \& Deneke, 2015; Mustapha et al., 2010; Howard et al., 2006) have not yet focused on nursing students. Another observation from existing studies is that a greater proportion has told the story without capturing the views or the perspective of students (Ballen et al., 2017). Although studies on student's classroom participation exist, empirical evidence from Africa is scarce (Schreiber \& Yu, 2016). In addition, it appears the previous studies have focused on students' participation in public institutions with little known about students of private institutions (Ballen et al.,2017; Abebe \& Deneke, 2015) and this is important especially when the prevailing conditions at a public university may differ from that of a private especially in many developing countries. The above reasons identified gives room for further studies.

The current study makes four key contributions to the literature on the subject matter. First, it is the first study to examine the drivers of undergraduate nursing students' classroom participation in Ghana. Second, it adds to the few studies that have provided evidence from the perspective of students. Third, it focuses on undergraduate nursing students which have not received much attention in the literature; and fourth, it adds to the few studies that have provided evidence from private universities. This study does that to bridge the gap identified from the review of existing studies. Gathering evidence from Ghana is premised on two reasons. In the first place although empirical evidence from Africa is scarce, that of Ghana is scarcer. Again, many nursing faculty members are of the view that nursing students do not participate in class and since that may have implication on the quality of nursing professionals that will be churn out in the future it is imperative to understand the factors behind that. Consequently, the study examines the undergraduate nursing students' perspectives on student-related, faculty-related and classroom climate factors affecting their participation in the classroom in a private university.

\section{METHOD \\ Study design and setting}

The researchers adopted a descriptive cross-sectional design to find out factors influencing classroom participation among undergraduate nursing students. The setting for the study was Presbyterian University College (PUC), Ghana, specifically the Asante-Akyem Agogo campus which hosts the Department of Nursing.

\section{Sampling technique and Sample Size}

The population for the study was 314 nursing students from levels 200, 300 and 400. Students in level 100 were excluded from the study because they had not reported to campus at the time of data collection. Again, students who did not give consent were excluded from the study. A sample size of 100 was used. Stratified random sampling which is a form of probability sampling was the sampling technique used in the study. In this type of method, people are classified into groups according to some characteristics, such as position, rank, income, education, sex, or ethnic background and referred to as strata (Alvi, 2016). In this study, the educational levels of the students were used as the strata. Three strata were used: level 200, level 300 , and level 400 . A random sample is selected from each stratum based upon the percentage that each subgroup represents in the population (Alvi, 2016). The last stratum (level 400) had majority of students and hence a higher proportion of participants were randomly selected from there as compared to other two strata (level 200 and 300).

\section{Data Collection tool Data Analysis}

Data was collected using a Likert scale questionnaire developed by the researchers. Participants were asked to specify their level of agreement or disagreement to certain statements. Data was collected between $10^{\text {th }}$ September and $1^{\text {st }}$ October, 2018. The questionnaires retrieved from the respondents were serially numbered to facilitate identification. The responses to the various items were also coded. Data was grouped and subjected to statistical analysis using the Statistical Package for Social Scientists (SPSS Version 21).

\section{Ethical Consideration}

Participation in this study was voluntary after the purpose and benefits of the research was explained to participants. Participants were made to know they could decide to opt out at any point in time and would not be forced or intimidated. Anonymity and confidentiality of the participants were maintained by ensuring that their identities are not revealed in any part of the research.

\section{RESULTS \\ Demographic characteristics of undergraduate nursing students}

Descriptive characteristics of the family caregivers are presented in Table 1 . The results in table 1 showed that majority of respondents (81\%) were between the ages of $21-26$ years, $15 \%$ were between $15-20$ years, $2 \%$ were between 27-31 years and another 25 were between 32-36 years old. Majority of respondents (94\%) were single, $6 \%$ were married whilst none was divorced. On the level of respondents, $40 \%$ were in level 400, 30\% were in level 300 and level 200 . Furthermore, as high as $93 \%$ of respondents were Christians whereas $7 \%$ were Muslims. In addition, majority of respondents (77\%) were females whilst $23 \%$ were males.

\section{Level of Participation}

The current study showed that majority of nursing students (52\%) often participated in the classroom, $17 \%$ participated very often, and $31 \%$ did not participate often. 
Student factors that affect classroom participation The results from table 1 shows that out of the 100 respondents, majority agreed that inadequate preparation (60\%), being afraid of speaking in front of mates (54\%), afraid of appearing unintelligent (51\%), poor command over English language (65\%), being shy $(74 \%)$, receiving negative evaluation from classmates (58\%) affected their participation in class. On the other hand, majority disagreed that desire to remain anonymous (74\%), other students dominating discussion (60\%), having a boyfriend/girlfriend (78\%) hindered them from participating in class. Only a minority of students (21\%) did not participate because they perceived it as being unimportant.

Table 1

Student factors affecting classroom participation

\begin{tabular}{|c|c|c|c|}
\hline Variables & $A(\%)$ & $\mathrm{N}(\%)$ & $\mathrm{D}(\%)$ \\
\hline $\begin{array}{l}\text { Inadequate preparation before the lecture hinders my ability to } \\
\text { participate in class. }\end{array}$ & 60 & 20 & 20 \\
\hline $\begin{array}{l}\text { I am afraid of speaking in front of the whole class and it prevent me } \\
\text { from participating. }\end{array}$ & 54 & 16 & 30 \\
\hline I am afraid of appearing unintelligent, so I do not participate in class. & 51 & 14 & 35 \\
\hline $\begin{array}{l}\text { I do not have control over English language which is the main means } \\
\text { of communication, hence I do not participate in class. }\end{array}$ & 65 & 7 & 28 \\
\hline I am often shy of my course mates so I do not participate in class. & 74 & 10 & 16 \\
\hline $\begin{array}{l}\text { I am afraid of negative evaluation from colleagues so I do not } \\
\text { participate. }\end{array}$ & 58 & 13 & 29 \\
\hline $\begin{array}{l}\text { I have a boyfriend/girlfriend in the class so I do not participate } \\
\text { because I do not want to be embarrassed in front of them. }\end{array}$ & 9 & 13 & 78 \\
\hline $\begin{array}{l}\text { I desire to remain anonymous especially to my lectures so I do not } \\
\text { like participation in class. }\end{array}$ & 23 & 26 & 51 \\
\hline $\begin{array}{l}\text { When some students dominate the classroom participation, it does } \\
\text { not encourage me to participate. }\end{array}$ & 28 & 12 & 60 \\
\hline $\begin{array}{l}\text { I do not participate because I do not perceive classroom participation } \\
\text { as important }\end{array}$ & 21 & 5 & 74 \\
\hline
\end{tabular}

Faculty factors that affect classroom participation of students

Table 2 shows that of the 100 respondents, majority agreed that they participate when the lecturer does not criticize contributions (80\%), gives adequate wait time (72\%), mentions name (74\%), offers equal opportunity
(63\%), awards marks (57\%), asks open ended questions. The gender of the lecturer was not found to affect participation as majority disagreed (73\%). Majority of the respondents $(63 \%)$ did not participate when the lecturer likes embarrassing students.

Table 2

Faculty factors affecting classroom participation

\begin{tabular}{|c|c|c|c|}
\hline Variables & Agree & Neutral & Disagree \\
\hline $\begin{array}{l}\text { I participate when the lecturer usually builds on my contributions but does } \\
\text { not condemn or criticize me. }\end{array}$ & 80 & 4 & 16 \\
\hline $\begin{array}{l}\text { I participate when the lecturer and I are of the same gender (male-male } \\
\text { or female-female). }\end{array}$ & 15 & 12 & 73 \\
\hline $\begin{array}{l}\text { I do participate when the lecturer gives adequate wait time for us to } \\
\text { digest information and give comments. }\end{array}$ & 72 & 9 & 19 \\
\hline I participate when the lecturer mentions my name to contribute. & 74 & 13 & 13 \\
\hline $\begin{array}{l}\text { I participate when the lecturer offers equal opportunities for us to } \\
\text { participate. }\end{array}$ & 63 & 11 & 26 \\
\hline I participate when lecturer awards marks for classroom participation. & 57 & 23 & 20 \\
\hline I participate when the lecturer asks open ended or analytical questions. & 52 & 23 & 25 \\
\hline I do not participate when the lecturer is unfriendly. & 42 & 19 & 39 \\
\hline I do not participate when the lecturer is boring. & 48 & 27 & 25 \\
\hline $\begin{array}{l}\text { I do not participate when the lecturer likes embarrassing student in front } \\
\text { of classmates. }\end{array}$ & 63 & 16 & 21 \\
\hline
\end{tabular}


Classroom climate factors influencing classroom participation

The majority of the respondents disagreed that temperature of the classroom (53\%), time of lecture in the day (56), sitting position in class (51\%) did affect their participation in classroom discussions. On the other hand, majority agreed that large class size (54\%) and the traditional classroom setting (62\%) influenced their classroom participation. The results are presented in figure 1.

\section{Figure 1}

Classroom climate factors affecting classroom participation

Classroom climate factors inhibiting participation

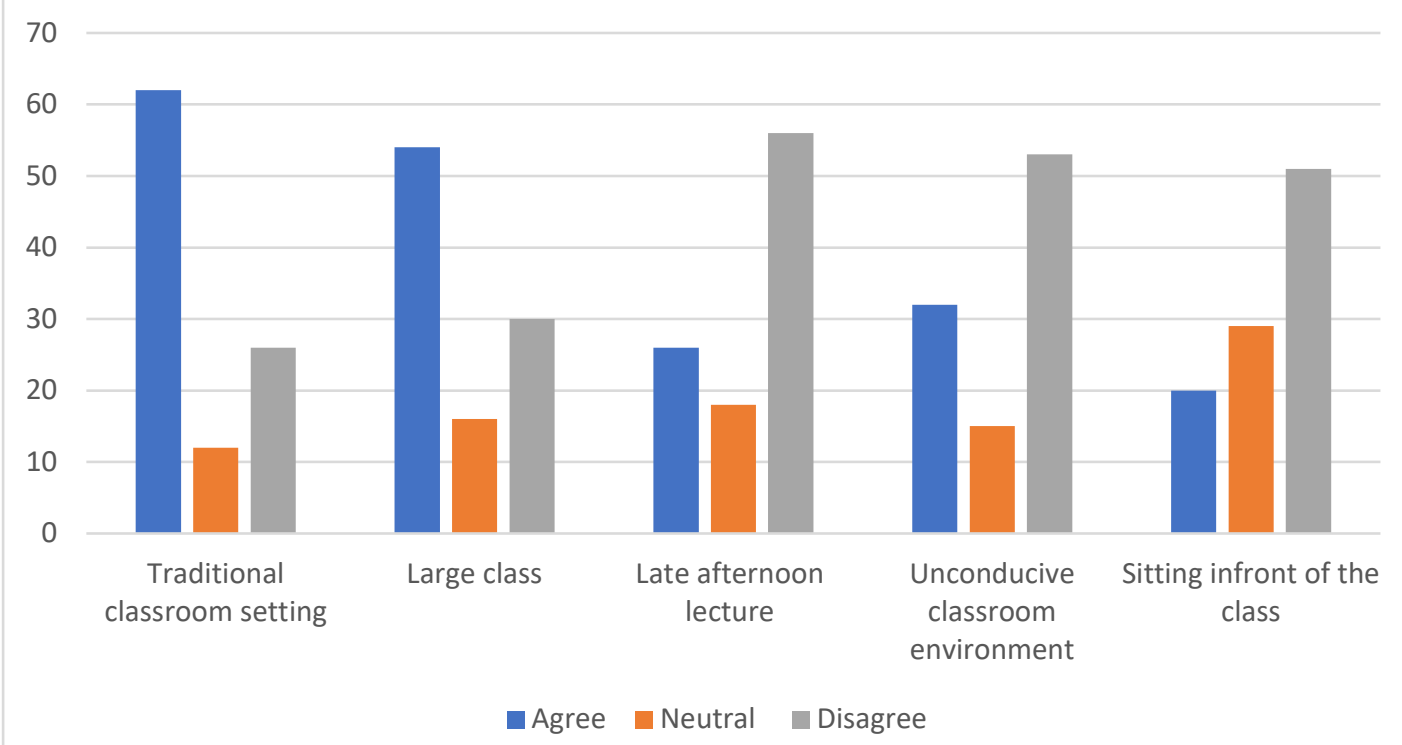

\section{Classroom participation and demographic} variables

From the table 3 below, there was significant relationship between classroom participation and age, marital status and educational level at $5 \%$ level of significance as more Level 400 students, male students, christians, and the married appear to participate more.

Table 3

ANOVA results for classroom participation and students' demographic variables

\begin{tabular}{lll}
\hline Variables & Mean & p \\
\hline Gender & 3.78 & .204 \\
Male & 3.32 & \\
Female & & \\
Religious affiliation & 3.71 & .053 \\
Christian & 3.41 & \\
Muslim & & \\
Marital status & 3.46 & .045 \\
Married & 4.00 & \\
Single & & \\
Age(years) & 3.60 & \\
15-20 & 3.49 & .042 \\
21-26 & 2.00 & \\
$27-31$ & 1.00 & \\
32-36 & & .030 \\
Educational level & 3.67 & \\
Level 400 & 3.33 & \\
Level 300 & 3.33 & \\
Level 200 & & \\
\hline
\end{tabular}




\section{DISCUSSION}

\section{Level of Classroom Participation}

The current study showed that majority of nursing students often participated in the classroom and it is most likely they perceived participation as very important. According to the expectancy value model, the student's expectation about the chances of attaining the incentives associated with participation and the value placed on that incentive will motivate participation. This shows that perception is very likely to influence an individual's behaviour. The finding is not consistent with a study done by Pokess and McDaniel (2011) which found that nursing students did not participate in class discussions.

\section{Student factors influencing classroom participation of undergraduate nursing students} The main student factor that was reported to affect participation was being shy of their colleagues. Other studies have also found shyness as a factor inhibiting participation (Kheleghi, 2016; Moffet et al., 2014; Howard et al., 2002). People who are shy may be very critical of what others may think and say about them. From the perspective of the force field theory, such students may not have congruence between the perception of themselves and the nature of the education programme. It is not surprising that most students were not willing to participate because they were afraid of receiving negative evaluation from their classmates. Students when counselled may improve on their self-esteem which can help them overcome this challenge.

Majority of nursing students reported that they do not have command over the English language which affected their level of participation and this is similar to a study by Susak (2016). It is likely that when students are given other alternate means to communicate apart from the English language, they will be more willing and feel at ease to participate. Students may sometimes understand the concept but lack the ability to explain due to poor command over the language. Inadequate preparation before the lecture was one other factor which majority of nursing students mentioned prevented them from participating. Inadequate preparation is likely to narrow students' scope of the concept of topic being discussed, decrease their confidence and subsequently decrease participation. This is consistent with other studies (Abebe \& Deneke, 2015; Mustapha, Rahman \& Yunus, 2010).

Faculty related factors influencing classroom participation of undergraduate nursing students

The findings of the current study showed that the main faculty factor which influenced participation was when the lecturer built on students' contribution. When students' contributions are not condemned, it is likely to boost the confidence and also be an extrinsic motivation for the student to read more. As the students explores more on the subject matter, they are more likely to contribute in subsequent discussions. Other studies have also reported that students keep quiet when they wanted to avoid criticisms from their lecturer (Susak, 2016; Abebe \& Deneke, 2015). Concerning adequate wait time, majority agreed that it influenced their level of participation since they were able to organize their thoughts before putting it across.
The current study found that students were likely to participate when their names were mentioned by the lecturer. The names of the students can be mentioned but can be done after the question is posed. When it happens the other way around, other students may feel the question was not for them and be unwilling to participate. On the contrary, Abebe and Deneke (2015) and Arafat (2012) reported that students get more anxious when called upon to respond individually.

Majority of nursing students participated when marks were awarded for that. No student would like to lose marks especially if it affected their overall grade. Similarly, Sommer and Sommer (2007) also found that class participation increased when associated with course credits. The expectancy value model indicates that if the student does not place value on the outcome of participation, it is unlikely for him/her to participate and vice versa. In the current study, gender of the lecturer did not affect participation which is not consistent with a study done by Hall and Sandler (1982). What probably may influence the students to participate is the teaching skills and methods of the lecturer as well as the personality.

\section{Classroom factor and students' classroom participation}

Concerning classroom climate factors affecting classroom participation, the majority of respondents stated that they were reluctant to participate in a traditional classroom setting. In the traditional classroom set up, the teacher stands in front of the class and it mostly appears the communication is between the lecturer and those seated in front. Thus, if the student finds him/herself at the back, participation may decrease. This may also explain why those who sit in front are not nervous, the lecturer may concentrate on those at the back. Similarly, a study conducted by Rocca (2010) showed that the physical arrangement of student desk in a traditional, forwardfacing rows with the lecturer positioned in the front of the room decreases participation.

The findings indicate that majority of the respondents were not willing to participate in large classes. In large classes other students may not participate for several reasons. First and foremost, it is likely to find the regular participants, so other students are likely to think even if they do not participate others would do. Again, others have performance anxiety especially in front of the whole class. On the other hand, if the class size is small, there may not be anyone to participate but you. In a similar study, students reported that smaller size of class and small group activity made it easier for them to participate (Susak, 2016; Moffet et al., 2014). On the contrary, Crombie, Pyke, Silverthorn, Jones, and Piccinin (2003) failed to find a significant impact of class size. The time of day for the lecture was not found to influence participation. Abdullah, Abu Bakar and Mahbob (2012) and Rocca (2010) in their studies that classes that was held in the evening decreased classroom participation.

Students demographic variables and participation The study further sought to explore the relationship between the participants demographic variables and participation. There was significant relationship between age, marital status and level and classroom 
participation. In the Ghanaian culture, marriage is revered and gives someone a particular social status. Married people may therefore feel more reluctant to participate. In the current study, respondents with lesser ages tend to participate. It is likely that as one increases in age, there may be other responsibilities to deal with which may give divided attention. Other studies have reported that age does not affect participation (Moffet et al., 2014; Crombie, Pyke, Silverthorn, Jones \& Piccinin, 2003). On the contrary, some studies have found that increasing age is associated with increased participation (Howard, James, \& Taylor 2002; Howard \& Baird, 2000). Respondents in higher levels tend to participate more than those in lower levels. Moffet et al. (2014) and Fritschner (2000) found that higher levels are associated with increased participation.

As students progress through the various levels, their confidence level may increase. No significant relationship was found between gender and classroom participation. Some studies have also found that the there is no significant relationship between gender and classroom participation (Kheleghi, 2016; Howard, James \& Taylor, 2002). On the contrary other studies have showed that females participated less than males (Aziz, Quraishi \& Kazi, 2018; Ballen et al., 2017; Yaylaci \& Beauvais, 2017).

\section{CONCLUSION AND RECOMMENDATION}

Classroom participation has garnered a great of positive attention, and it is not entirely undeserved because participation of students in class help to develop critical way of thinking and practically developing problem solving skills that would be useful in their professional development and other aspect of self-development. The result of this study provides some insights into the student, lecturer and classroom climate factors influencing participation.

The study showed that undergraduate nursing students are most likely to participate when they have prepared adequately for class. Allowing adequate wait time, offering students the equal opportunities to participate and awarding marks for participation were found to be the most likely faculty factors to influence students to participate. The time of the lecture during the day did not influence the participation of the students but the only factor that seemed to influence participation was class size. Clearly, classroom participation is not entirely one dimensional as all the key stakeholders have a role to play to ensure participation is effective and also the maximum benefit is derived from it.

The above findings call for the following recommendations:

- The lecturers in the university should establish expectations of participation. They should also encourage students, this is likely to boost the confidence of students to speak in class, negative evaluations and comments by classmates should condemned by lecturers to make room for low esteemed and shy students to be able to participate in class. Lecturers should also ensure that their lectures are understandable and interesting lessons. In addition to the above, the questions should be simple and prepared in advance if possible, should be given to students in advance. Lecturers are to allow enough time after questions are posed. Finally, they should learn the names of their students and move around in class.

- Student should take upon themselves to adequately prepare themselves before lectures so that they are not found in an uncomfortable situation. Student should also foster good relationship amongst each other, friendly and give motivation to each other.

- The management of the university college should provide a conducive atmosphere for learning by providing good, comfortable furniture and learning materials for student and lecturers to work with. Large class sizes can be divided in smaller sizes to foster participation.

\section{ACKNOWLEDGEMENT}

The authors of this work wish to express their profound gratitude to undergraduate nursing students of the Presbyterian University College, Ghana for their support during the data collection.

\section{REFERENCES}

Abdullah, M.Y., Bakar, A. \& Mahbob, M.H. (2012). Student's participation in classroom: What motivates them to speak up? Social and Behavioral Sciences, 51, 516-522.

Abebe, D.T. \& Deneke, T. (2015). Causes of students' limited participation in EFL classroom: Ethiopian public universities in focus. Inter. J. Edu. Res. Technol. 6(1), 74-89. doi: 10.15515/ijert.09764089.6.1.7489.

Alvi, M.H. (2016). A manual for selecting sampling techniques in Research. Pakistan: University of Karachi, Iqra University.

Arafat, H. (2012). An exploration of causes of Saudi students' reluctance to participate in the English Language classroom. International Journal of English Language Education,1, 17-34.

Aziz, F., Quraishi, U. \& Kazi, A.S. (2018). Factors behind classroom participation of secondary School students (a gender-based analysis). Universal Journal of Educational Research, 6, 211-217. 10.13189/ujer.2018.060201.

Ballen, C., Danielsen, M., Jørgensen, C., Grytnes, J. \& Cotner, S. (2017). Norway's gender gap: classroom participation in undergraduate introductory science. Nordic Journal of STEM Education, 1(1), 262-270.

Benner, P., Stuphen, M., Leonard, V., \& Day, L. (2010). Educating nurses: $A$ call for radical transformation. San Francisco, CA: JosseyBass.

Bozak, M. (2003). Using Lewin's Force Field Analysis in implementing a nursing information system. Journal of Nursing Management, 21(3), 80-85.

Billings, D., \& Halstead, J. (2009). Teaching in Nursing: A Guide for Faculty (2nd ed.). St. Louis, MO: Elsevier Saunders.

Crombie, G., Pyke, S.W., Silverthorn, N., Jones, A. \& Piccinin, S. (2003). Students' perceptions of their classroom participation and instructor as function of gender and context. The Journal of Higher Education, 74, 51-76.

Daggett, L.M. (1997). Quantifying class participation. Nurse Education, 22(2), 13-4. 
Dallimore, E. J., Hertenstein, J. H. \& Platt, M. B. (2004). Classroom participation and discussion effectiveness: student-generated strategies. Communication Education, 5(1), 103-115.

Dancer, D., \& Kamvounias, P. (2005). Student involvement in assessment: A project designed to assess class participation fairly and reliably. Assessment \& Evaluation in Higher Education, 30, 445-454.

Fassinger, P.A. (1995). Professors' and students' perceptions of why students participate in class. Teaching Sociology, 24, 25-33.

Fritschner, L.M. (2000). Inside the undergraduate college classroom: Faculty and students differ on the meaning of student participation. The Journal of Higher Education, 71, 342-62.

Garside, C. (1996). Look who's talking: A comparison of lecture and group discussion teaching strategies. Communication Education, 45(3), 212.

Girgin, K. Z., \& Stevens, D. D. (2005). Bridging in-class participation with innovative instruction: Use and implications in a Turkish university classroom. Innovations in Education and Teaching International, 42(1), 93-106.

Hall, R.M. \& Sandler, B.R. (1982). "The Classroom Climate: A Chilly One for Women?" Washington, DC: Project on the Status and Education of Women, Association of American Colleges.

Howard, J. R., \& Henney, A. L. (1998). Student participation and instructor gender in the mixedage college classroom. Journal of Higher Education, 69 (4), 384-405.

Howard, J.R., James, G.H., \& Taylor, D.R. (2002). The consolidation of responsibility in the mixed-age college classroom. Teaching Sociology,30(2), 214-234.

Kheleghi, A. (2016). Identification of affective factors influencing students' low participation in university EFL oral classes: An Iranian Case Study. International Journal of Humanities and Social Science, 6, 7.

Lau, Y. (2014). Factors affecting the social problemsolving ability of baccalaureate nursing students. Nurse Education Today, 34(1), 121-126.

Loftin, C., Davis, L. A., \& Hartin, V. (2010). Classroom participation: A student perspective. Teaching and Learning in Nursing, 5(3), 119-124.

McCleary, D.F., Aspiranti, K.B., Foster, L.N., Blondin, C.A., Galyon, C.E., Yaw, J.S...Williams, R.L. (2011). Balancing participation across students in a large college courses via randomized participation credit. Journal of General Education, 64,194-214.

Moffet, J., Berezowski, J., Spencer, D. \& Laning, S. (2014). An investigation into the factors that encourage learner participation in a large group medical classroom. Advances in Medical Education and Practice, 5, 65-71.

Mustapha, M. S., Nik-Abd-Rahman, S. N., \& Yunus, M. M. (2010). Factors influencing classroom participation: a case study of Malaysian undergraduate students. Procedia Social and Behavioral Sciences, 9, 1079-1084.

Nunn, C.E. (1996). Discussion in the college classroom: Triangulating observational and survey Results. The Journal of Higher Education, 67, 243-266.

Phelps, K., Henry, A.L., \& Bird, W.A. (2012). Factors influencing or discouraging secondary school students' FFA participation. Journal of Agricultural Education, 53(2), 70-86. doi: 10.5032/jae.2012.02070

Pokess, A. M. \& McDaniel, A. (2011). Our nursing students engaged learning? A secondary analysis of data from the national survey of student engagement. Nursing Education Perspectives, 32(2), 89-94

Rocca, K.A. (2010). Student participation in the college classroom: An extended multidisciplinary literature review. Communication Education, 59(10), 185-213.

Schreiber, B. \& Yu, D. (2016). Exploring student engagement practices at a South African university: student engagement as a reliable predictor of academic performance. South African Journal of higher education, 30(5), 157175.

Sommer, R. \& Sommer, B. A. (2007). Credit for comments, comments for credit. Teaching of Psychology, 34, 104-106.

Susak, M. (2016). Factors that affect classroom participation. Thesis. Rochester Institute of Technology. Accessed fromhttps://scholarworks.rit.edu/theses/9370.

Tatar, S. (2005). Why keep silent? the classroom participation experiences of non-native-englishspeaking students. Language and Intercultural Communication, 5(3-4), 284-293.

Tedesco-Schneck, M. (2016). Factors that influence classroom participation of junior-and senior-level nursing students. PhD thesis. Retrieved $20^{\text {th }}$ December, 2018.

Weaver, R.R., \&Qi, J. (2005). Classroom organization and participation: College students' perceptions. $\mathrm{J}$ Higher Educ, 76, 570-601.

Yaylaci, S. \& Beeauvais, E. (2017). The role of social group membership on classroom participation. Political Science \& Politics, 50(2), 559-564. 